\title{
Position Paper on the Value of Extended Adjuvant Therapy with Neratinib for Early HER2+/HR+ Breast Cancer
}

\author{
Marija Balic $^{a} \quad$ Gabriel Rinnerthaler $^{\mathrm{b}}$ Rupert Bartsch ${ }^{c}$ \\ aDivision of Oncology, Department of Internal Medicine, Medical University Graz, Graz, Austria; ${ }^{b}$ Department of \\ Internal Medicine III with Haematology, Medical Oncology, Haemostaseology, Infectiology and Rheumatology, \\ Oncologic Center, Salzburg Cancer Research Institute - Laboratory for Immunological and Molecular Cancer \\ Research (SCRI-LIMCR), Paracelsus Medical University, Salzburg, Austria; 'Division of Oncology, Department of \\ Medicine 1, Medical University of Vienna, Vienna, Austria
}

\section{Keywords}

HER2-positive breast cancert - Co-positive breast cancer · Early breast cancer · Extended adjuvant therapy · Neratinib

\footnotetext{
Abstract

Background: In August 2018, neratinib - an oral, irreversible pan-HER-tyrosine-kinase inhibitor - was approved by the European Commission for the extended adjuvant treatment of adult patients with early-stage, hormone receptor-positive (HR+), HER2 overexpressed/amplified (HER2+) breast cancer who completed trastuzumab-based adjuvant therapy within the last year. Despite recent improvements in long-term outcome, there is still an unmet need to further reduce the risk of recurrence, especially in patients with poor response to neoadjuvant treatment. Summary: National and international guidelines included recommendations for using neratinib. Based on the health technology assessment for neratinib, the Federal Joint Committee (G-BA) in Germany has granted an added benefit for neratinib compared with the standard "watch and wait" strategies. Inclusion in the Reimbursement Code, however, was rejected by the Austrian social insurance companies in July 2020, and neratinib is now in the "No Box" for individual head physician reimbursement. Key Messages: We analysed the value of extended adjuvant therapy with neratinib in early HER2+/HR+ breast cancer based on current data and made recommendations for the evidence-based and economical use of neratinib in
}

Austria. In particular, prognostic factors associated with an increased risk of recurrence following standard therapy are considered. Extended adjuvant therapy should be offered primarily to nodal-positive patients at surgery. For nodalnegative patients, neratinib therapy may be considered in case of large and/or inflammatory primary tumours (T3-4) without pathological complete response after neoadjuvant therapy. For all other patients, neratinib may be considered depending on additional risk factors on an individual basis that should be evaluated by interdisciplinary tumour conferences.

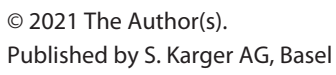

\section{Introduction}

Human epidermal growth factor receptor 2 (HER2) protein overexpression and/or gene amplification of the HER2/neu gene occurs in about $15-20 \%$ of early breast cancers and is associated with an increased recurrence risk and a poorer prognosis compared to HER2-negative (HER2-) disease without HER2-targeted therapy $[1,2]$. HER2+ breast cancer with simultaneous hormone receptor overexpression ( $\mathrm{HR}+$ ) (luminal B/HER2-positive, also called "triple-positive") affects around $10 \%$ of all breast cancer patients [3-7].

In contrast to locally advanced-inoperable and metastatic situations, the potentially curable stages I-III are mercial purposes requires written permission. 


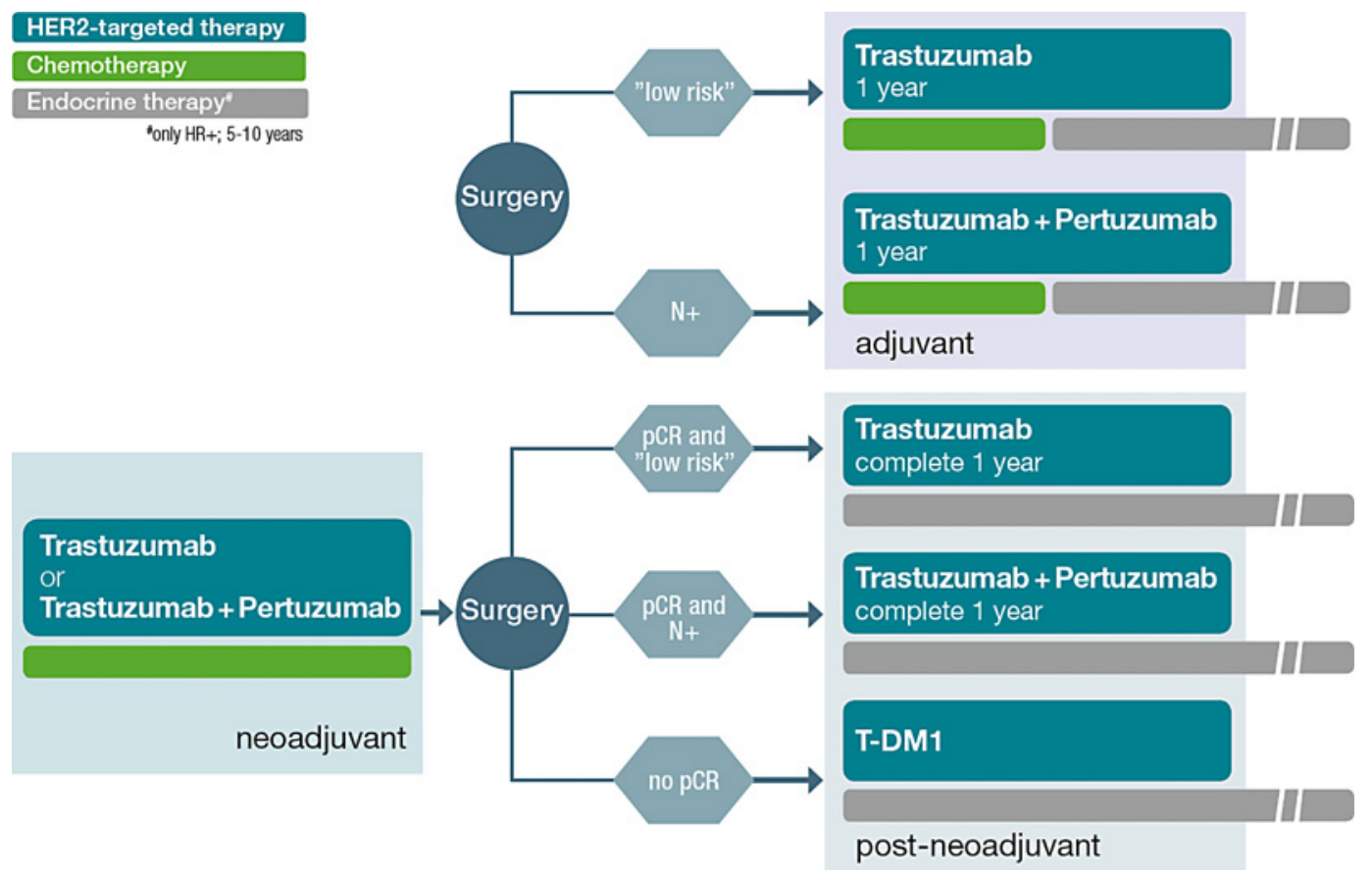

Fig. 1. Current therapy algorithm for the treatment of early HER2+ breast cancer. Schematic representation adapted in accordance with the current recommendations of the German working group Gynecological Oncology (AGO) [8] and the European Society of Medical Oncology $[15,18]$. The decision on adjuvant systemic therapies should be based on an individual's risk of relapse, the predicted sensitivity to the treatment, the benefit and toxicities [15]. According to the EMA label, neratinib use is approved after

referred to as early breast cancer and are usually treated with a combination of locoregional surgical therapy (plus radiotherapy if indicated) and chemotherapy combined with HER2-directed targeted neoadjuvant and/or (postneo)adjuvant systemic therapy plus endocrine therapy in luminal B/HER2-positive disease $[8,9]$.

The aim of early breast cancer therapy is to prevent locoregional recurrences and development of distant metastases. Although the prognosis of patients with early HER2+ breast cancer has improved significantly in recent decades thanks to the introduction of targeted anti-HER2 therapies $[10,11]$, up to $31 \%$ of patients are at risk of recurrence and/or death after 10 years with adjuvant chemotherapy plus trastuzumab, depending on the individual risk [10]. Patient's prognosis is determined primarily by the stage and biology of the breast cancer and by the presence of individual risk factors. In addition to achieving pathological complete response (pCR), the relevant prognostic factors in early HER $2+$ breast cancer are hormone receptor status, tumour size, nodal status, and age [12-14].

Role of Extended Adjuvant Therapy with Neratinib any trastuzumab-based therapy, including (postneo-)adjuvant pertuzumab and/or T-DM1. It should be noted that patients in the ExteNET study did not receive pertuzumab or T-DM1, as these drugs had not been available at study start [31, 32]. HER2, human epidermal growth factor receptor 2; HR, hormone receptor; N, lymph node/nodal status; surgery, operative tumour resection; pCR, pathological complete response; T-DM1, trastuzumab-emtansine.

\section{Treatment Options for Early HER2+ Breast Cancer according to Current Guidelines}

In accordance with international guidelines (AGO, ESMO, ASCO, NCCN guidelines), patients receive neoadjuvant and/or (post-neo)adjuvant (perioperative) targeted anti-HER2 therapy (trastuzumab or trastuzumab + pertuzumab and/or T-DM1) embedded in a chemotherapy regimen for the systemic treatment of early HER2+ breast cancer [8, 15-18].

Endocrine therapy is indicated as the standard therapy for all patients with hormone-sensitive breast cancer and is usually administered as an adjuvant therapy for HER $2+1$ HR+ breast cancer [7, 15-19].

Figure 1 shows, in simplified form, the current therapy algorithm according to the European guidelines. 
Table 1. Overview of recurrence probabilities and the frequency of peripheral recurrence and brain metastases in early HER2+ breast cancer after various pre-treatments

\begin{tabular}{|c|c|c|c|c|c|}
\hline \multirow[t]{2}{*}{$\begin{array}{l}\text { Study [Ref.] } \\
\text { Setting; therapy }\end{array}$} & \multicolumn{2}{|c|}{$\begin{array}{l}\text { Probability of recurrence } \\
\text { after } 3 \text { years }^{\mathrm{a}}\end{array}$} & \multicolumn{2}{|c|}{$\begin{array}{l}\text { Probability of recurrence } \\
\text { after } x \text { years }^{\mathrm{a}}\end{array}$} & \multirow{2}{*}{$\begin{array}{l}\text { Frequency of peri- } \\
\text { pheral recurrence/BM } \\
\text { (total patients with BM) }\end{array}$} \\
\hline & all patients & $\mathrm{HR}+$ & all patients & $\mathrm{HR}+$ & \\
\hline $\begin{array}{l}\text { Pooled analysis }^{\mathrm{b}} \\
{[11,20,21]^{\mathrm{a}}} \\
\text { Adjuvant; trastuzumab }(n=2,028)\end{array}$ & $12.0 \%$ & $7.8 \%$ & $\begin{array}{l}\text { After } 10 \text { years } \\
26.3 \%\end{array}$ & $18.6 \%$ & 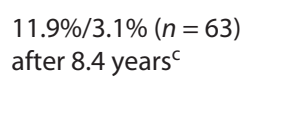 \\
\hline $\begin{array}{l}\text { HERA }[10,22] \text { adjuvant; trastuzumab (1 year) } \\
(n=1,552 / 1,702)\end{array}$ & $13.3 \%$ & $10.4 \%$ & $\begin{array}{l}\text { After } 10 \text { years } \\
31 \%\end{array}$ & $28 \%$ & $\begin{array}{l}17.9 \% / 2.6 \%(n=45) \\
\text { after } 11 \text { years }^{\mathrm{d}}\end{array}$ \\
\hline $\begin{array}{l}\text { APHINITY }[12,23] \text { adjuvant; pertuzumab + trastuzumab } \\
(n=2,400)\end{array}$ & $\begin{array}{l}5.9 \% \\
\mathrm{~N}+: 8.0 \%\end{array}$ & $5.2 \%$ & $\begin{array}{l}\text { After } 6 \text { years } \\
9.4 \% \\
\mathrm{~N}+: 12.1 \%\end{array}$ & $8.8 \%$ & $\begin{array}{l}5.9 \% / 2.0 \%(n=49) \text { after } \\
6.2 \text { years }^{\mathrm{e}}\end{array}$ \\
\hline $\begin{array}{l}\text { KATHERINE [13] post-neoadjuvant, non-pCR } \\
\text { trastuzumab-emtansine }(n=742)\end{array}$ & $11.7 \%$ & $9.3 \%$ & n.r. & n.r. & $\begin{array}{l}10.5 \% / 5.9 \%(n=44) \\
\text { after } 3.5 \text { years }{ }^{f}\end{array}$ \\
\hline $\begin{array}{l}\text { Neoadjuvant CT }+ \text { anti-HER2 therapy } \\
\text { Patients with pCR after neoadjuvant CT [14]; (T1-2/N-: } \\
n=212 ; \mathrm{T} 3-4 / \mathrm{N}-; n=65 \\
\mathrm{~T} 1-2 / \mathrm{N}+: n=200 ; \mathrm{T} 3-4 / \mathrm{N}+; n=60)\end{array}$ & n.r. & n.r. & $\begin{array}{l}\text { After } 5 \text { years } \\
\text { n.r. }\end{array}$ & $\begin{array}{l}\mathrm{T} 1-2 / \mathrm{N}-: 8.6 \% \\
\mathrm{~T} 3-4 / \mathrm{N}-: 13.0 \% \\
\mathrm{~T} 1-2 / \mathrm{N}+: 16.4 \% \\
\mathrm{~T} 3-4 / \mathrm{N}+: 19.6 \%\end{array}$ & n.r. \\
\hline
\end{tabular}

${ }^{a}$ Calculated with 1 minus Kaplan-Meier estimator at the relevant time; ${ }^{b}$ NSABP B-31 and NCCTG N9831 studies; ${ }^{c-f}$ median follow-up times $\left({ }^{e}\right.$ calculated from 74.1 months; ${ }^{f}$ calculated from 41.1 months). BM, brain metastases; HR, hormone receptor; $\mathrm{N}+$ /-, nodal-positive/-negative; pCR, pathological complete response; $\mathrm{CT}$, chemotherapy; n.r., not reported.

\section{Recurrence Risk}

Despite optimal (neo)adjuvant treatment, distant recurrences are still observed with longer follow-up. The recurrence risk is particularly high for patients who do not achieve a pCR after neoadjuvant therapy. Higher tumour size and nodal involvement additionally increase recurrence risk in these patients. However, for patients with pCR after neoadjuvant therapy, but high initial tumour burden or inflammatory disease (T3-4 and/or involved lymph nodes), there is a considerable risk of recurrence as well (Table $1[10-14,20-23]$ ).

Of note, the risk profile and recurrence patterns differ between the non-luminal and luminal B/HER2+ subgroups. In HR/HER2 co-expressing tumours, a lower pCR rate has been described [24], while the correlation between $\mathrm{pCR}$ and long-term outcome is less pronounced [25]. For patients with HER2+/HR- disease, the risk of recurrence is especially high within the first 5 years, and decreases constantly thereafter. In contrast, the risk of recurrence is initially lower in the HER $2+/ \mathrm{HR}+$ subgroup, but also remains constant beyond the first 5 years (Fig. 2) [26-29], suggesting a potential benefit from the extension of adjuvant therapy.

\section{Neratinib - Overview of the Product Characteristics}

- Approved indication(s)

- July 2017 USA/FDA [30]: "extended adjuvant treatment of adult patients with early stage HER 2 -overexpressed/amplified breast cancer, to follow adjuvant trastuzumab-based therapy."

- August 2018 EU/EMA [31, 32]: "extended adjuvant treatment of adult patients with early-stage hormone receptor positive HER2-overexpressed/ amplified breast cancer and who completed adjuvant trastuzumab-based therapy less than 1 year ago."

- February 2020 USA/FDA [33]: in addition, "in combination with capecitabine, for the treatment of adult patients with advanced or metastatic HER2positive breast cancer who have received two or more prior anti-HER2 based regimens in the metastatic setting."

- March 2020 Switzerland/Swissmedic [34]: "extended adjuvant treatment of adult patients with earlystage hormone-receptor positive HER2-overexpressed/amplified breast cancer who are less than 1 year from the completion of prior adjuvant therapy based on trastuzumab and chemotherapy."

- Pharmacological classification ATC L01XE45 [32, 35]: Oral, irreversible pan-HER tyrosine kinase inhibitor. Unlike HER2-targeted antibodies (such as trastuzumab, 
A

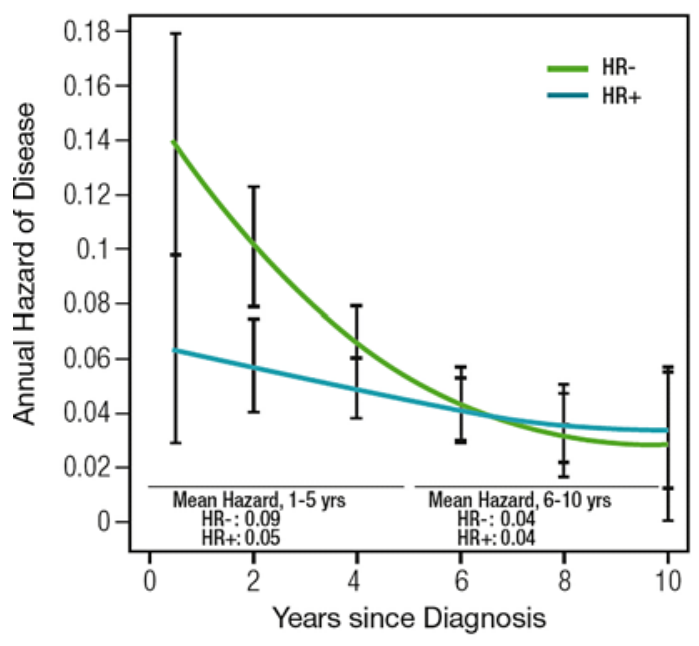

B

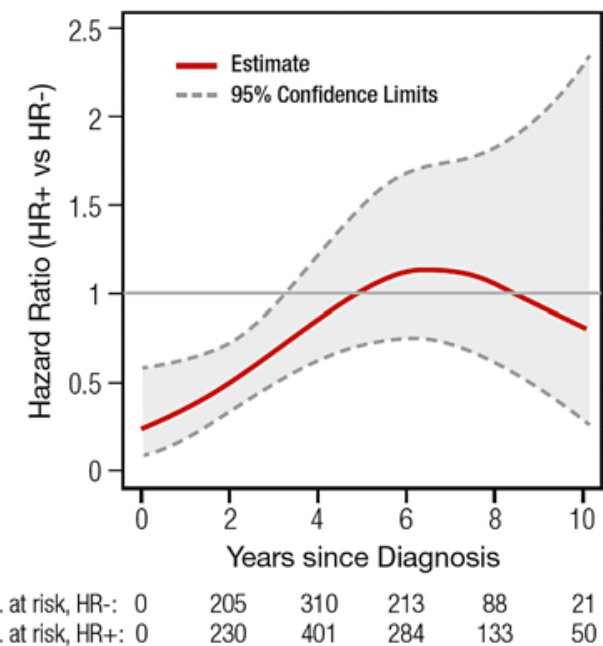

Fig. 2. Annual hazards and time-dependent hazard ratios for recurrence in HER2+ patients by HR status. A Annual hazards for recurrence in HER2+, placebo-treated patients from the TEACH study (lapatinib vs. placebo in patients with adjuvant pre-treatment) by HR status (95\% CIs for 2-year intervals). B Hazard ratio for recurrence in HER2+, placebo-treated patients from the TEACH study (lapatinib vs. placebo in patients with adjuvant pre- treatment [chemotherapy, but no trastuzumab]), comparison of HR+ vs. HR- (modified from Strasser-Weippl et al. [28]). Copyright license: (c) 2015 Strasser-Weippl K, Horick N, Smith IE, et al.Published by Breast Cancer Research under the CC BY license which permits unrestricted use, distribution, and reproduction in any medium, provided the original work is properly credited. Disclaimer of warranties and limitation of liability apply.

Table 2. Baseline patient characteristics in the intention-to-treat (ITT) population [36] and the EMA label population [38] of the ExteNET study

\begin{tabular}{|c|c|c|c|c|}
\hline & \multicolumn{2}{|c|}{ Baseline characteristics ITT } & \multicolumn{2}{|c|}{$\begin{array}{l}\text { Baseline characteristics EMA-label population } \\
(\mathrm{HR}+,<1 \text { year after trastuzumab) }\end{array}$} \\
\hline & $\begin{array}{l}\text { neratinib } \\
(n=1,420)\end{array}$ & $\begin{array}{l}\text { placebo } \\
(n=1,420)\end{array}$ & $\begin{array}{l}\text { neratinib } \\
(n=670)\end{array}$ & $\begin{array}{l}\text { placebo } \\
(n=664)\end{array}$ \\
\hline Median age (range), years & $52(25-83)$ & $52(23-82)$ & $51(25-83)$ & $51(23-78)$ \\
\hline Pre-/postmenopausal, \% & $47 / 53$ & $47 / 53$ & $52 / 48$ & $42 / 48$ \\
\hline Endocrine therapy simultaneously with neratinib, \% & 93 & 94 & 93 & 95 \\
\hline $0 / 1-3 / \geq 4$ involved lymph nodes, $\%$ & $24 / 47 / 30$ & $24 / 47 / 30$ & $19 / 51 / 30$ & $19 / 50 / 31$ \\
\hline Median time after trastuzumab (range), months & $4.4(0.2-30.9)$ & $4.7(0.3-40.6)$ & $3.1(0.2-12.0)$ & $3.3(0.3-12.0)$ \\
\hline Patients with previous neoadjuvant therapy, $\%$ & 24 & 27 & 24 & 29 \\
\hline
\end{tabular}

pertuzumab or T-DM1), which bind extracellularly to the HER2 receptor, neratinib irreversibly binds to the intracellular tyrosine kinase domains of HER1 (EGFR), HER2 and HER4 and therefore impedes intracellular HER2 signal-transduction and the formation of active heterodimers with HER3 (HER3 has no tyrosine kinase domain). - Dosage [32]:

One orally administered daily dose of $240 \mathrm{mg}$ (equivalent to 6 tablets of $40 \mathrm{mg}$ ) for 1 year. Treatment must be initiated within 1 year after completion of trastuzumabbased therapy.

- Prophylaxis [31, 32]:
Concomitant systematic diarrhoea prophylaxis starting with the first dose of neratinib is recommended for the first 1-2 months.

\section{Overview of Study Data on Neratinib with a Focus on the Approved Indication}

Approval is based on the international, multicentre, randomised, placebo-controlled phase III study ExteNET, in which 2,840 patients with early HER2+ breast cancer participated [36-38]. 
A

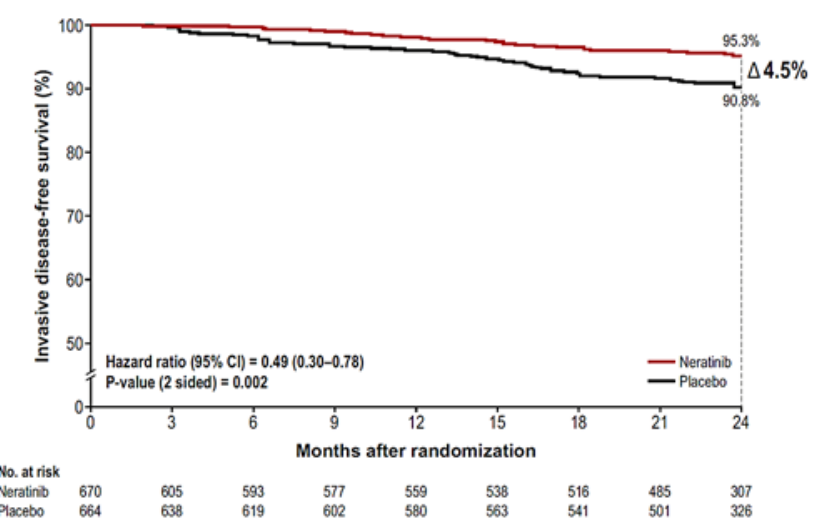

C

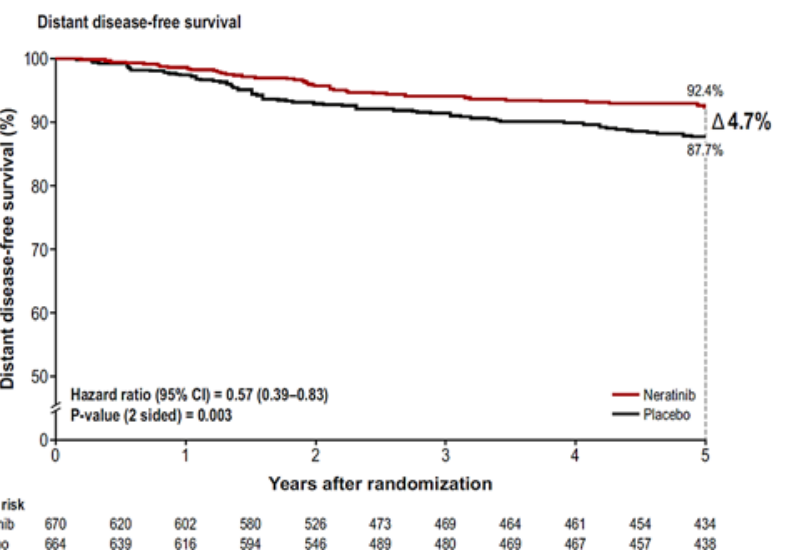

B
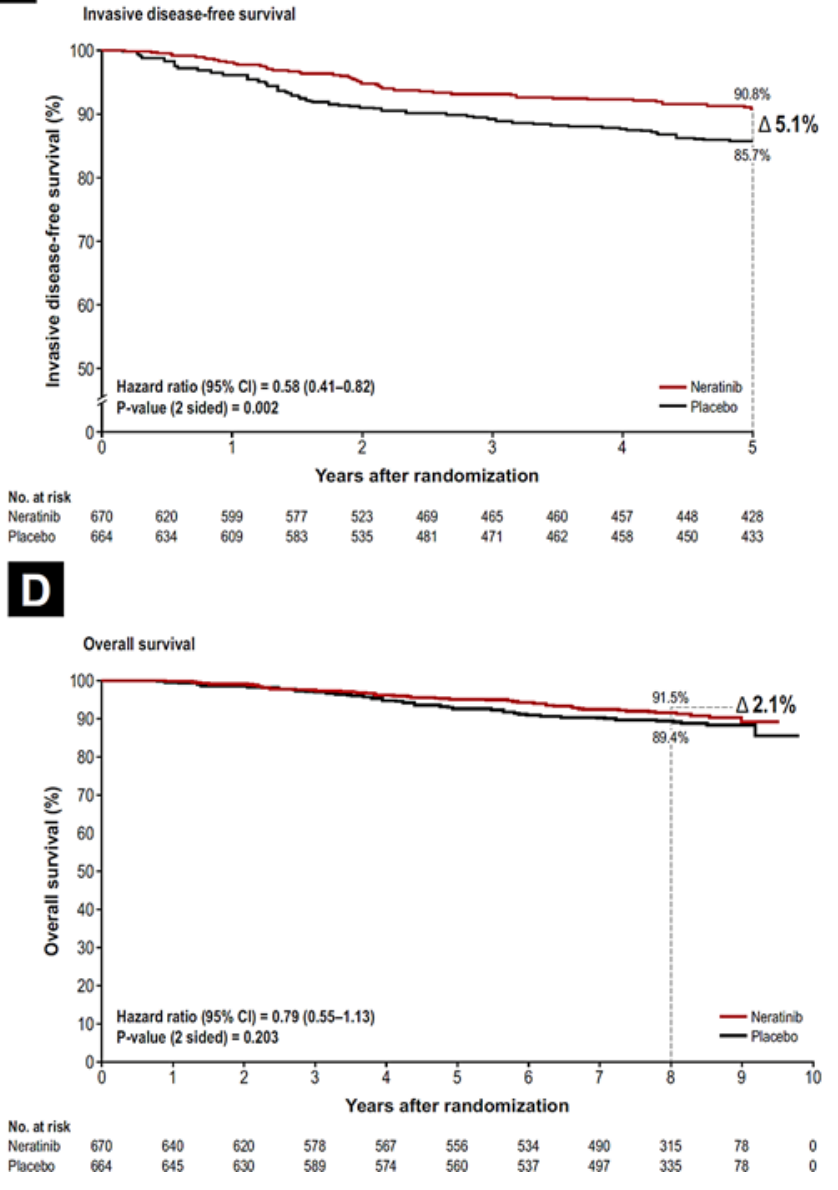

Fig. 3. Invasive disease-free survival at 2 years $(\mathbf{A})$ and 5 years (B), distant disease-free survival at 5 years (C), and overall survival (D) - EMA label population [38]. Copyright license: (C) 2020 Chan A, Moy B, Mansi J, et al.Published by Elsevier Inc. under the CC BY-

Key features of the Phase III ExteNET study (see also Supplementary Fig. 1 [34, 36-38]):

- HER2+ operable breast cancer, stage I-IIIc, HR+/-.

- Extended adjuvant neratinib $240 \mathrm{mg}$ /day versus placebo for 1 year following (neo)adjuvant trastuzumab therapy.

- Primary endpoint: Invasive disease-free survival (iDFS) after 2 years (follow-up analysis after 5 years) in the intention-to-treat (ITT) population.

- Secondary endpoints: overall survival (OS) (analysis planned after 248 events), disease-free survival (including ductal in situ carcinoma), distant disease-free survival (DDFS), time to recurrence of distant metastases, incidence of CNS recurrence, safety, tolerability.

- Inclusion phase: 2009-2011; duration of study: median follow-up at primary analysis: 24 months in both arms; median follow-up at 5-year analysis: 5.2 years
NC-ND license which permits to share, copy and redistribute the material, provided the original work is properly credited. Disclaimer of warranties and limitation of liability apply.

under neratinib versus 5.3 years under placebo; medial follow-up for OS at 8.0 years in both arms.

The patient baseline characteristics are summarised in Table 2.

In extended adjuvant therapy following trastuzumabbased (neo)adjuvant treatment, the ExteNET study of neratinib showed a significant improvement in iDFS compared to the placebo (2-year iDFS in the ITT population 93.9 vs. $91.6 \%$; HR 0.67 [95\% CI $0.50-0.91] ; p=0.0091$ ) [36]. A follow-up analysis 5 years after randomisation confirmed the benefit of neratinib versus placebo [37].

The HR+ subgroup of patients in particular as well as those starting neratinib therapy within 1 year after end of trastuzumab-based therapy benefited from neratinib [36, 38 ], and the European approval of neratinib was granted for the 1-year extended adjuvant treatment of HER2/HR co-positive breast cancer patients who finished trastu- 
Fig. 4. Invasive disease-free survival (A), distant disease-free survival (B), and overall survival (C) - subgroup of non-pCR patients after neoadjuvant therapy from the EMA label population - 5-year analysis [38]. Copyright license: (c) 2020 Chan A, Moy B, Mansi J, et al.Published by Elsevier Inc. under the CC BY-NC-ND license which permits to share, copy and redistribute the material, provided the original work is properly credited. Disclaimer of warranties and limitation of liability apply.
A Invasive disease-free survival

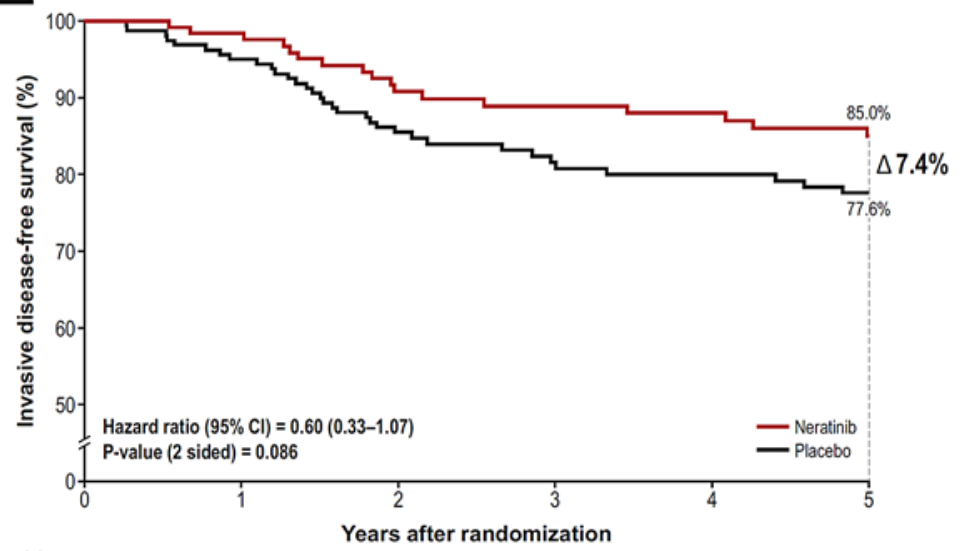

No. at risk

$\begin{array}{llllllllllll}\text { Neratinib } & 131 & 126 & 121 & 113 & 100 & 94 & 93 & 91 & 91 & 88 & 84 \\ \text { Placebo } & 164 & 159 & 151 & 143 & 125 & 107 & 103 & 99 & 99 & 98 & 94\end{array}$

B

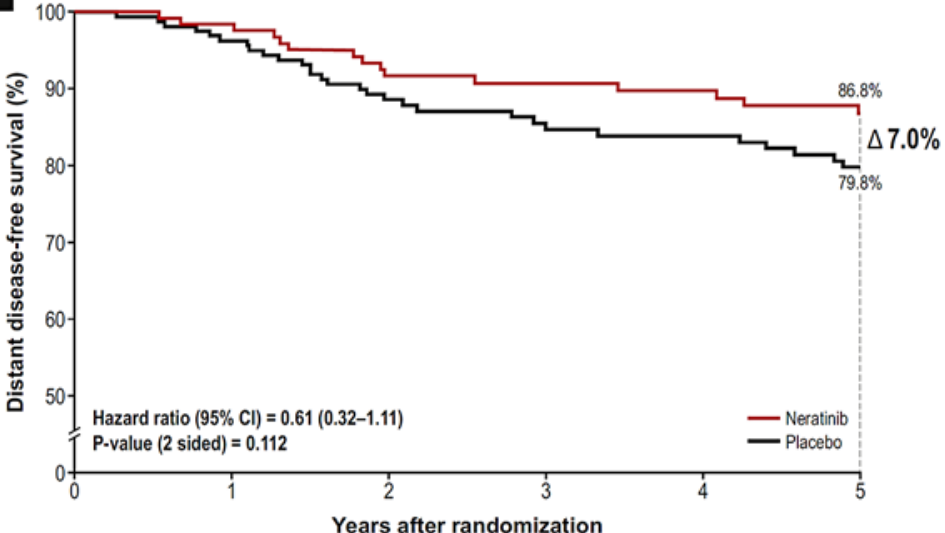

No. at risk

Neratinib

Neratinits

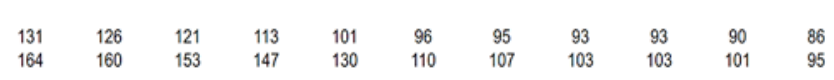

C

Overall survival

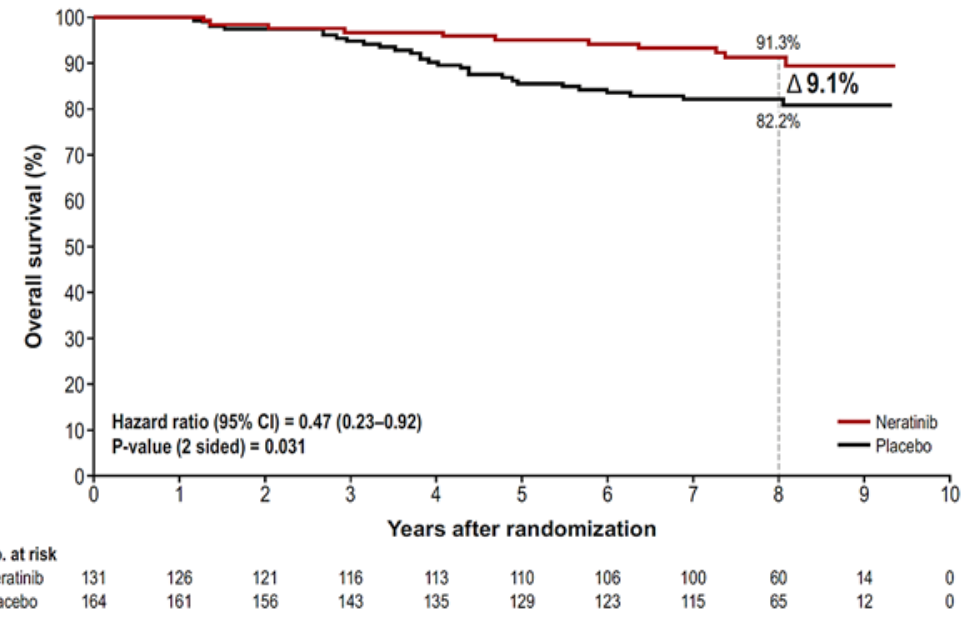


zumab-based pre-therapy less than 1 year ago ("EMAlabel population") $[31,32]$. Table 2 shows baseline characteristics for patients of the ITT population and the EMA-label population $[36,38]$.

\section{Efficacy in the EMA Label Population of the ExteNET Study}

- Significant prolongation of iDFS (endpoint included recurrence of invasive disease in the ipsi- or contralateral breast, locoregional recurrence, distant metastases, death from any cause) with 5.1\% absolute and $35.7 \%$ relative reduction in the probability of recurrence or death after 5 years (HR 0.58 [95\% CI 0.41 0.82 ], $p=0.002$, Figure 3B). iDFS after 5 years was $90.8 \%$ in the neratinib group and $85.7 \%$ in the placebo group [38].

- Significant improvement in DDFS (endpoint included distant metastases, death of any cause) with a $4.7 \%$ absolute and $38.2 \%$ relative reduction in the probability of occurrence of distant metastases or death after 5 years (HR 0.57 [95\% CI 0.39-0.83]; $p=0.003$; Figure $3 \mathrm{C})$. DDFS after 5 years was $92.4 \%$ in the neratinib group and $87.7 \%$ in the placebo group [38].

- An exploratory post-hoc analysis showed that those patients who had completed neratinib therapy $(\geq 11$ months therapy duration, $n=402$ ) derived the most pronounced benefit with a $7.4 \%$ absolute and $51.4 \%$ relative reduction in the probability of recurrence or death after 5 years (HR 0.44 [95\% CI 0.28-0.68]). iDFS after 5 years was $93.1 \%$ in the neratinib group and $85.7 \%$ in the placebo group [39].

- In the cumulative incidence of CNS recurrences, albeit the number of events was low in both arms, there was a numerical difference in favour of the neratinib group after 5 years (neratinib: 0.7\% [95\% CI 0.2-1.7], 4 CNS events; placebo: $2.1 \%$ [95\% CI 1.1-3.5], 12 CNS events). CNS-disease-free survival (CNS-DFS) after 5 years was $98.4 \%$ in the neratinib group and $95.7 \%$ in the placebo group (HR 0.41 [95\% CI 0.18-0.85], 9 vs. 23 events) [38].

- After a median follow-up of 8.0 years, 53 out of 670 patients (7.9\%) in the neratinib group and 68 out of 664 patients $(10.2 \%)$ in the placebo group had died (HR 0.79 [95\% CI 0.55-1.13]). OS after 8 years was $91.5 \%$ in the neratinib group and $89.4 \%$ in the placebo group, an absolute difference of $2.1 \%$ between the groups [38].

- Of the 354 patients (27\% of the EMA label population) who had received neoadjuvant therapy, 295 patients (83\%) had invasive residual disease (non-pCR) after completion of neoadjuvant therapy, 38 patients (11\%) achieved pCR, and no result was reported for $21 \mathrm{pa}-$ tients (6\%) [38].
For patients with residual invasive disease $(n=295)$, the absolute risk reduction for iDFS and DDFS after 5 years was 7.4\% (HR 0.60 [95\% CI 0.33-1.07]; $p=0.086$ ) and $7.0 \%$ (HR 0.61 [95\% CI 0.32-1.11]; $p=0.112$, Figure $4 \mathrm{~A}$ and $\mathrm{B})$, respectively [38]. The OS rates showed an absolute risk reduction of $9.1 \%$ (HR 0.47 [95\% CI $0.23-$ $0.92] ; p=0.031$, Figure $4 \mathrm{C}$ ). In the cumulative incidence of CNS recurrences in these patients, there was a numerical difference in favour of the neratinib group after 5 years (neratinib: $0.8 \%$ [95\% CI 0.1-4.0], 1 CNS event; placebo: 3.6\% [95\% CI 1.3-7.8], 5 CNS events). CNS-DFS after 5 years was $98.4 \%$ in the neratinib group and $92.0 \%$ in the placebo group (HR 0.24 [95\% CI 0.04-0.92], 2 vs. 10 events) [38].

For patients without evidence of residual invasive disease (pCR) after neoadjuvant therapy $(n=38)$, the absolute risk reduction for iDFS was $9.8 \%$ after 5 years (HR 0.44 [ $95 \%$ CI $0.06-1.89]$ ]) and for OS $19.6 \%$ after 8 years (HR 0.40 [95\% CI 0.06-1.88]) [38]. In the cumulative incidence of CNS recurrences, there was a numerical difference in favour of the neratinib group after 5 years (neratinib: 0 [95\% CI NE]; placebo: 5.0\% [95\% CI 0.3-21.2], 3 CNS events). iDFS after 5 years was $100 \%$ in the neratinib group and $81.9 \%$ in the placebo group [38]. Due to the low number of patients in this subgroup, no final conclusions regarding the efficacy of extended adjuvant therapy in patients with $\mathrm{pCR}$ seem possible.

Patient-Reported Outcomes/Quality of Life in the ITT Population of the ExteNET Study

Therapy with neratinib showed a slight decrease in global health-related quality of life scores as evaluated by FACT-B (Functional Assessment of Cancer TherapyBreast) and EQ-5D in the first month compared to placebo (adjusted mean differences: FACT-B overall: -2.9 points; EQ-5D index: -0.02 ); thereafter, the differences between the groups decreased. Except for the FACT-B subscale on physical well-being in month 1 , none of the group differences exceeded the "important differences" (IDs) [40]. The FACT-B breast cancer-specific subscale showed small improvements with neratinib in months 3-9, but again below the IDs. Sensitivity analyses taking into account missing data showed no change in outcome.

\section{Safety/Tolerability in the EMA Label Population of} the ExteNET Study

In general, the well-described safety profile of neratinib is typical for tyrosine kinase inhibitors of the HER receptor family and therefore predictable [32, 35-38, 4143]. Unlike other agents used in the therapy of early breast cancer, no cumulative or irreversible toxicities were observed [37, 44-48].

The most common adverse event during neratinib treatment in the EMA-label population of the ExteNET 
Table 3. Characteristics of diarrhoea under neratinib therapy in the ExteNET and CONTROL studies (safety population; datacut for dose escalation cohort: Oct 19, 2020, datacut for all other CONTROL study cohorts: Oct 21, 2019) [53, 54]

\begin{tabular}{|c|c|c|c|c|c|c|}
\hline & \multicolumn{5}{|l|}{ CONTROL } & \multirow{2}{*}{$\frac{\text { ExteNET }}{n=1,408}$} \\
\hline & $n=137$ & $n=64$ & $n=136$ & $n=104$ & $n=60$ & \\
\hline Neratinib dose & $\begin{array}{l}\text { Neratinib } \\
240 \mathrm{mg} / \mathrm{d}\end{array}$ & $\begin{array}{l}\text { Neratinib } \\
240 \mathrm{mg} / \mathrm{d}\end{array}$ & $\begin{array}{l}\text { Neratinib } \\
240 \mathrm{mg} / \mathrm{d}\end{array}$ & $\begin{array}{l}\text { Neratinib } \\
240 \mathrm{mg} / \mathrm{d}\end{array}$ & $\begin{array}{l}\text { Neratinib dose } \\
\text { escalationc }\end{array}$ & $\begin{array}{l}\text { Neratinib } \\
240 \mathrm{mg} / \mathrm{d}\end{array}$ \\
\hline Loperamide prophylaxis & $\begin{array}{l}\text { Loperamide }^{\mathrm{a}} \\
\text { first } 8 \text { weeks }\end{array}$ & $\begin{array}{l}\text { Loperamide } \\
\text { first } 8 \text { weeks }\end{array}$ & $\begin{array}{l}\text { Loperamide }^{b} \\
\text { first } 4 \text { weeks }\end{array}$ & & & $\begin{array}{l}\text { No primary } \\
\text { prophylaxis }\end{array}$ \\
\hline Other diarrhea prophylaxis & & $\begin{array}{l}\text { Budesonide } \\
9 \mathrm{mg} / \mathrm{d} \text { for } \\
1 \mathrm{cycle}\end{array}$ & $\begin{array}{l}\text { Colestipol } \\
2 \mathrm{~g} \text { bid for } \\
1 \text { cycle }\end{array}$ & $\begin{array}{l}\text { Colestipol } \\
2 \mathrm{~g} \text { bid for } \\
1 \text { cycle }\end{array}$ & & \\
\hline \multicolumn{7}{|c|}{ Treatment-emergent diarrhoea incidence, $n$ (\%) } \\
\hline No diarrhoea & $28(20)$ & $9(14)$ & $23(17)$ & $5(5)$ & $1(1.7)$ & $65(5)$ \\
\hline Grade 1 & $33(24)$ & $16(25)$ & $38(28)$ & $34(33)$ & $24(40)$ & $323(23)$ \\
\hline Grade 2 & $34(25)$ & $21(33)$ & $47(35)$ & $32(31)$ & $27(45)$ & $458(33)$ \\
\hline Grade 3 & $42(31)$ & $18(28)$ & $28(21)$ & $33(32)$ & $8(13.3)$ & $561(40)$ \\
\hline Grade 4 & 0 & 0 & 0 & 0 & 0 & $1(<1)$ \\
\hline \multicolumn{7}{|l|}{ Characteristics of grade $\geq 3$ diarrhoea } \\
\hline Median episodes/patient (IQR) & $1(1-2)$ & $1(1-2)$ & $1(1-2)$ & $1(1-3)$ & 2 (n.r.) & $2(1-3)$ \\
\hline Median duration of episode, days (IQR) & $2(1-3)$ & $1(1-2)$ & $1(1-2)$ & $1(1-2)$ & n.r. & $2(1-3)$ \\
\hline Median time to first episode, days (IQR) & $7(5-13)$ & $19(7-45)$ & $41(7-189)$ & $15(8-47)$ & 45 (n.r.) & $8(4-33)$ \\
\hline Median cumulative duration ${ }^{d}$, days (IQR) & $3(2-6)$ & $3(1-3)$ & $4(1-6)$ & $2(1-6)$ & 2.5 (n.r.) & $5(2-9)$ \\
\hline \multicolumn{7}{|l|}{ Action taken, $n(\%)$} \\
\hline Dose hold & $20(15)$ & $12(19)$ & $22(16)$ & $15(14)$ & $7(11.7)$ & $477(34)$ \\
\hline Dose reduction & $10(7)$ & $3(5)$ & $10(7)$ & $12(12)$ & $2(3.3)$ & $372(26)$ \\
\hline Discontinuation & $28(20)$ & $5(8)$ & $5(4)$ & $8(8)$ & $2(3.3)$ & $237(17)$ \\
\hline Hospitalization & $2(1)$ & 0 & 0 & 0 & 0 & $20(1)$ \\
\hline
\end{tabular}

a 4 mg initial; days 1-14: 4 mg tid; days 15-56: 4 mg bid; b 4 mg initial; days 1-14: 4 mg tid; days 15-28: 4 mg bid; ' dose escalation regimen \#1: days 1-7: $120 \mathrm{mg} / \mathrm{d}$; days 8-14: $160 \mathrm{mg} / \mathrm{d}$, then $240 \mathrm{mg} / \mathrm{d}$; dose escalation regimen \#2 (days 1-14: $160 \mathrm{mg} / \mathrm{d}$; days 15-28: $200 \mathrm{mg} / \mathrm{d}$, then $240 \mathrm{mg} / \mathrm{d}$ ) is not reported here; ${ }^{d}$ defined as the sum of the durations of all episodes at that grade. Unless otherwise mandated, all patients received loperamide as needed (16 $\mathrm{mg} / \mathrm{d}$ maximum) on days 1 - 364. IQR, interquartile range; n.r., not reported.

study was diarrhoea (all grades) at $94.6 \%[32,35,36-38$, 44; see also Supplementary Table 1]. Other common adverse events (all grades; $\geq 20 \%$ ) were: nausea, $43.7 \%$; fatigue, 28.5\%; vomiting, 26.3\%; and abdominal pain, $23.6 \%$.

Severe diarrhoea (grade 3) was reported in the EMAlabel population of the ExteNET study with a frequency of $39.4 \%$ in the neratinib arm and $1.1 \%$ in the placebo arm (grade 4 was not observed) [38]. In the neratinib arm, grade 3 diarrhoea was reported to occur relatively early after therapy start (median time to first occurrence: 8 days); the median cumulative duration of grade 3 diarrhoea was 5 days [44].

It should be noted, however, that no systematic anti-diarrhoeal prophylaxis was mandated by the study protocol in the ExteNET study $[36-38,44]$. Accordingly, frequency and severity of diarrhoea that occurred in the ExteNET study cannot be equated with the current reality of care.

\section{Diarrhoea Prophylaxis as Part of the Neratinib Risk}

Management Plan

Based on the summary of product characteristics and the EMA risk management plan established for neratinib, systematic anti-diarrhoeal prophylaxis and detailed therapy management is now required as part of routine treatment - in contrast to the ExteNET study [31, $32,49-51]$.

In addition, the multi-cohort phase II CONTROL study has been initiated as a clinical trial for further optimisation of anti-diarrhoeal strategies with neratinib [5254]. The inclusion criteria are comparable to those of the ExteNET study; the primary endpoint is the frequency of diarrhoea with severity (grade) $\geq 3$.

The interim analysis shows that systematic diarrhoea prophylaxis initiated with the first dose of neratinib, accompanied by an appropriate diarrhoea management, can significantly reduce incidence of diarrhoea, its duration and severity $[53,54]$ (Table 3 ):

- In the different cohorts, $13.3-32 \%$ of patients had grade 3 diarrhoea; grade 4 diarrhoea was not observed. 
Table 4. Guidelines with recommendations for the use of neratinib in the treatment of early HER2+ breast cancer

\begin{tabular}{|c|c|c|c|c|}
\hline Guidelines & Recommendation & $\begin{array}{l}\text { Evidence } \\
\text { level }\end{array}$ & $\begin{array}{l}\text { Grading of rec- } \\
\text { ommendation }\end{array}$ & Sources \\
\hline $\begin{array}{l}\text { ASCO } 2020 \\
\text { American Society of } \\
\text { Clinical Oncology }\end{array}$ & $\begin{array}{l}\text { Extended adjuvant therapy with neratinib in patients with HER2-positive early breast } \\
\text { cancer } \\
\text { Neratinib causes relevant diarrhoea and diarrhoea prophylaxis should be applied }\end{array}$ & High & Moderate & [16] \\
\hline $\begin{array}{l}\text { ESMO } 2019 \\
\text { European Society for } \\
\text { Medical Oncology }\end{array}$ & $\begin{array}{l}\text { Extended anti-HER2 therapy with neratinib combined with appropriate diarrhoea } \\
\text { prophylaxis and treatment may be considered in selected high-risk patients who have } \\
\text { not previously been treated with a double blockade (especially HR+ patients) }\end{array}$ & I & B & {$[15,18]$} \\
\hline $\begin{array}{l}\text { NCCN } 2020 \\
\text { National Comprehensive } \\
\text { Cancer Network }\end{array}$ & $\begin{array}{l}\text { Neratinib as a therapy option after adjuvant trastuzumab therapy in HER2+/HR+ } \\
\text { Mamma CA with a high risk of recurrence }(\mathrm{N}+) \text {; of note: no data is available for } \\
\text { patients who have previously received pertuzumab } \\
\text { Neratinib as a therapy option after adjuvant trastuzumab therapy in HER2+/HR+ } \\
\text { breast cancer and pCR after neoadjuvant therapy with a high risk of recurrence; of } \\
\text { note: no data is available for patients who have previously received pertuzumab or } \\
\text { T-DM1 }\end{array}$ & & $2 \mathrm{~A}$ & [17] \\
\hline $\begin{array}{l}\text { AGO } \\
\text { Gynaecological } \\
\text { Oncological } \\
\text { Working Group e.V. }\end{array}$ & $\begin{array}{l}\text { Neratinib combined with standard endocrine therapy after } 1 \text { year of adjuvant } \\
\text { trastuzumab }(\mathrm{HR}+) \\
\text { Neratinib combined with standard endocrine therapy after } 1 \text { year of post- } \\
\text { neoadjuvant trastuzumab (HR+, non-pCR) } \\
\text { Primary prophylaxis with loperamide }\end{array}$ & $\begin{array}{l}1 \mathrm{~b} / \mathrm{B} \\
3 \mathrm{~b} / \mathrm{B} \\
2 \mathrm{~b} / \mathrm{B}\end{array}$ & $\begin{array}{l}+ \\
+/- \\
++\end{array}$ & {$[8,55]$} \\
\hline
\end{tabular}

HER2, human epidermal growth factor receptor 2; HR, hormone receptor; Mamma CA, breast cancer; N, lymph node/nodal status; pCR, pathological complete response; T-DM1, trastuzumab-emtansine.

Table 5. Latest results for neratinib from European Health Technology Assessment (HTA) procedures [56-60]

\begin{tabular}{lll}
\hline Country/Institution & Therapeutic indication & HTA evaluation \\
\hline $\begin{array}{l}\text { Germany } \\
\text { Joint Federal Committee (G-BA) }\end{array}$ & $\begin{array}{l}\text { Nerlynx is indicated for the extended adjuvant treatment of adult } \\
\text { patients with hormone receptor-positive, HER2 overexpressed/amplified } \\
\text { early-stage breast cancer who completed trastuzumab-based adjuvant } \\
\text { therapy less than 1 year ago }\end{array}$ & $\begin{array}{l}\text { Added benefit (category: minor; } \\
\text { robustness category: hint) } \\
\text { compared to the appropriate } \\
\text { comparative therapy, i.e. watch } \\
\text { and wait }\end{array} \quad \begin{array}{l}\text { [56] } \\
\text { and }\end{array}$ \\
\hline
\end{tabular}

UK "[...] option for the extended adjuvant treatment of hormone receptor-

National Institute for Health and positive, human epidermal growth factor receptor 2 (HER2)-positive early

Care Excellence (NICE) Stage breast cancer in adults who completed adjuvant trastuzumab-

based therapy less than 1 year ago only if

- trastuzumab is the only HER2-directed adjuvant treatment they have

had, and

Recommended

- if they had neoadjuvant chemotherapy-based regimens, they still had residual invasive disease in the breast or axilla following the neoadjuvant treatment, and

- the company provides neratinib according to the commercial arrangement"

Scotland "Extended adjuvant treatment of adult patients with early-stage

Scottish Medicines Consortium hormone receptor positive HER2-overexpressed/amplified breast cancer (SMC) and who completed adjuvant trastuzumab-based therapy less than 1

Recommended year ago"

Sweden

Tandvårds- och

läkemedelsförmånsverket, (TLV)

"Indicated for the extended adjuvant treatment of adult patients with hormone receptor positive early-stage HER2 overexpressed/amplified breast cancer who have completed trastuzumab-based adjuvant treatment less than a year ago"

Austria
Nerlynx ${ }^{\oplus}$ is indicated for the extended adjuvant treatment of adult patients with hormone receptor-positive, HER2 overexpressed/amplified early-stage breast cancer who completed trastuzumab-based adjuvant therapy less than 1 year ago
Recom

Recommended

"No Box"

Patient-individual request for reimbursement is required, reim bursement can be granted by the insurance-based physician 
Table 6. Simplified overview of the most common situations where the use of extended adjuvant treatment with neratinib may be considered

\begin{tabular}{lll}
\hline Prognostic risk factors & Nodal-negative & Nodal-positive \\
\hline Neoadjuvant pretreatment, non-pCR & T3-4 & \\
Neoadjuvant pretreatment, pCR & T3-4 & All T-stages \\
Adjuvant (no neoadjuvant pretreatment) & Possibly also consider & \\
& Age, grading, Ki-67 & \\
\hline
\end{tabular}

Ki-67, proliferation marker Ki-67; (non-)pCR, (missing) pathological complete response after neoadjuvant therapy; $\mathrm{T}$, tumour size.
- Grade 3 diarrhoea occurred mainly within the first 1-2 months after starting neratinib therapy.

- Across all cohorts, the median cumulative duration of grade 3 diarrhoea ranged between 2 and 4 days in the CONTROL study, compared to 5 days in the ExteNET study.

- The different anti-diarrhoeal prophylaxis strategies present with different strengths and weaknesses. Thus, the strategy should be chosen on a patient-individual basis, taking into account patient preferences, comorbidities, and lifestyle factors.

- As the dose escalation cohort \#2 is still ongoing, results of this cohort are not shown here.

The neratinib dose escalation approach is particularly appealing, with $75 \%$ of patients completing the treatment (i.e., treatment duration of 11.06 months or longer) and the lowest incidence of grade 3 diarrhoea across all cohorts [54].

\section{Summary and Conclusions}

On the basis of the clinically relevant efficacy data described above, extended adjuvant therapy with neratinib is recommended in the therapeutic indication in accordance with the summary of product characteristics in international guidelines (Table $4[8,15-18,55])$.

In the course of various "Health Technology Assessment" procedures in Europe, the competent authorities have attributed an added benefit to neratinib in this setting (Germany) or recommended its use (UK, Scotland, Sweden) (Table 5 [56-59]).

For patients with HER2/HR co-positive breast cancer who are at increased risk of late recurrence, the primary therapeutic goal is to avoid distant metastases. In the pivotal ExteNET trial, the risk of local and distant recurrence was reduced to a statistically significant and clinically relevant extent by extended adjuvant therapy with neratinib compared to placebo, provided that neratinib therapy was started within 1 year after the end of trastuzumab-based adjuvant therapy [38]. Accordingly, this new treatment option was approved by the EMA for these patients.
The medical need for an additional reduction of the risk of recurrence by the use of extended adjuvant neratinib therapy should be assessed on the basis of the patient-specific risk factor constellations. The following factors should be considered:

- $\mathrm{pCR}$ or no pCR after neoadjuvant therapy

- Lymph node status

- Tumour size

- Further individual risk factors on a case-to-case basis In summary, extended adjuvant therapy should be offered primarily to patients with lymph node involvement. For nodal-negative patients, neratinib therapy may be considered in case of large and/or inflammatory primary tumours (T3-4) without pCR after neoadjuvant therapy or - depending on additional risk factors - if pCR was achieved after neoadjuvant therapy or after adjuvant therapy (Table 6).

In addition, individual risk factor constellations may justify the use of neratinib in individual patients based upon the recommendation of an interdisciplinary tumour conference.

In general, regular check-ups while on treatment with neratinib must be carried out by the relevant specialist department or centre or by a medical specialist in oncology.

\section{Acknowledgements}

The authors would like to acknowledge editorial support provided by Barbara Möller, Wien, Austria - Input and translation; Berres-Stenzel Grafikdesign, Freiburg, Germany - Graphics Design; Andreas Zähringer, Freiburg, Germany - editorial support.

\section{Statement of Ethics}

As this review article/position paper only considered publicly available literature and reports, a separate informed consent process was not implemented and no ethics approval was requested. 


\section{Conflict of Interest Statement}

Assoc. Prof. Marija Balic has disclosed a consulting role with Amgen, Astra Zeneca, Lilly, MSD, Novartis, Pierre Fabre, Pfizer, and Roche. She is currently receiving research funding from Pfizer and Novartis. She is on the speaker's bureau for Amgen, Astra Zeneca, Daiichi Sankyo, Eli Lilly, MSD, Novartis, Pierre Fabre, and Pfizer and has received travel accommodation and expenses from Astra Zeneca, Lilly, MSD, Novartis, Pfizer, and Roche.

Assoc. Prof. Rupert Bartsch has disclosed Advisory Roles at Astra-Zeneca, Celgene, Daiichi, Eisai, Eli-Lilly, MSD, Novartis, Pfizer, Pierre-Fabre, Puma, Roche, and Samsung; Lecture Honoraria from Accord, Astra-Zeneca, BMS, Celgene, Eli-Lilly, Novartis, Pfizer, Pierre-Fabre, Roche, and Sandoz and Research Support from Daiichi, MSD, Novartis, and Roche.

Dr. Gabriel Rinnerthaler has disclosed a consulting role with Pierre Fabre, Roche, Novartis, Pfizer, and Eli Lilly. He is currently receiving research funding from Roche. He is on the speaker's bureau for Amgen, AstraZeneca, Novartis, Bristol-Myers Squibb, Roche, Pfizer, and Eli Lilly and has received travel and accomodation expenses from Roche, Novartis, Amgen, Pfizer, and BristolMyers Squibb.

The authors have no other relevant affiliations or financial involvement with any organization or entity with a financial interest in or financial conflict with the subject matter or materials discussed in the article apart from those disclosed.

\section{Funding Sources}

Pierre Fabre Austria (Wels) provided financial support to fund medical writing activities.

\section{Author Contributions}

All named authors participated in the development of the manuscript and in the decision to submit this manuscript for publication. The authors meet the International Committee of Medical Journal Editors (ICMJE) criteria for authorship for this article, take responsibility for the integrity of the work as a whole, and have given their approval for this version to be published.

Marija Balic: conceptualization, methodology, writing-original draft preparation, writing-review, and editing; Gabriel Rinnerthaler: conceptualization, methodology, writing-original draft preparation, writing-review, and editing; Rupert Bartsch: conceptualization, methodology, writing-original draft preparation, writing-review, and editing.

\section{Data Availability Statement}

Due to the nature of this review article/position paper using solely publicly available literature and reports no new data was generated to be made available by the corresponding author.

\section{References}

1 Loibl S, Gianni L. HER2-positive breast cancer. Lancet. 2017;389(10087):2415-29.

2 Perrier A, Gligorov J, Lefèvre G, Boissan M. The extracellular domain of Her2 in serum as a biomarker of breast cancer. Lab Invest. 2018;98(6):696-707.

3 Arpino G, Weiss H, Lee AV, Schiff R, De Placido S, Osborne CK, et al. Estrogen receptorpositive, progesterone receptor-negative breast cancer: association with growth factor receptor expression and tamoxifen resistance. J Natl Cancer Inst. 2005;97(17):1254-61.

4 Dowsett M, Houghton J, Iden C, Salter J, Farndon J, A'Hern R, et al. Benefit from adjuvant tamoxifen therapy in primary breast cancer patients according oestrogen receptor, progesterone receptor, EGF receptor and HER2 status. Ann Oncol. 2006;17(5):818-26.

5 Martin M, Holmes FA, Ejlertsen B, Delaloge $\mathrm{S}$, Moy B, Iwata $\mathrm{H}$, et al. Neratinib after trastuzumab-based adjuvant therapy in HER2-positive breast cancer (ExteNET): 5-year analysis of a randomised, double-blind, placebo-controlled, phase 3 trial. Lancet Oncol. 2017; 18(12):1688-700.

6 Schrodi S, Eckel R, Hölzel D, Schubert-Fritschle G, Engel J. Outcome von Mammakarzinom-Patientinnen in Abhängigkeit von molekularen Subtypen, definiert anhand von Surrogatparametern - Eine bevölkerungsbezogene Analyse von Krebsregisterdaten. Senologie - Zeitschrift für Mammadiagnostik und -therapie. 2017;14(02):A1-A53.
7 Wörmann B, Aebi S, Balic M, et al. Onkope dia-Leitlinie Mammakarzinom der Frau. Januar 2018. Available from: https://www.onkopedia.com/de/onkopedia/guidelines/mam makarzinom-der-frau/@@guideline/html/ index.html [accessed 2020 Oct 22].

8 Arbeitsgemeinschaft Gynäkologische Onkologie e.V. (AGO) Kommission Mamma. Diagnostik und Therapie früher und fortgeschrittener Mammakarzinome - Adjuvante zytostatische und zielgerichtete Therapien. 2021. Available from: https:// www.ago-online.de/fileadmin/ago-online/ downloads/_leitlinien/kommission_mamma/2021/Einzeldateien/2021D_11_Adjuvante_zytostatische_und_zielrichtete Therapien_MASTER_final_20210302.pdf (accessed:29.04.2021)

9 Harbeck N, Gluz O, Christgen M, Kates RE, Braun M, Küemmel S, et al. De-escalation strategies in human epidermal growth factor receptor 2 (HER2)-positive early breast cancer (BC): final analysis of the West German Study Group adjuvant dynamic marker-adjusted personalized therapy trial optimizing risk assessment and therapy response prediction in early BC HER2- and hormone receptor-positive phase II randomized trial-efficacy, safety, and predictive markers for 12 weeks of neoadjuvant trastuzumab emtansine with or without endocrine therapy (ET) versus trastuzumab plus ET. J Clin Oncol. 2017; 35(26):3046-54.
10 Cameron D, Piccart-Gebhart MJ, Gelber RD, Procter M, Goldhirsch A, de Azambuja E, et al. 11 years' follow-up of trastuzumab after adjuvant chemotherapy in HER2-positive early breast cancer: final analysis of the HERceptin Adjuvant (HERA) trial. Lancet. 2017; 389(10075):1195-205.

11 Perez EA, Romond EH, Suman VJ, Jeong JH, Sledge G, Geyer CE, et al. Trastuzumab plus adjuvant chemotherapy for human epidermal growth factor receptor 2-positive breast cancer: planned joint analysis of overall survival from NSABP B-31 and NCCTG N9831. J Clin Oncol. 2014;32(33):3744-52.

12 Piccart M, Procter M, Fumagalli D, de Azambuja E, Clark E, Ewer MS, et al. Adjuvant pertuzumab and trastuzumab in early HER2positive breast cancer in the APHINITY trial: 6 years' follow-up. J Clin Oncol. 2021;39: 1448-1457.

13 von Minckwitz G, Huang CS, Mano MS, Loibl S, Mamounas EP, Untch M, et al. Trastuzumab emtansine for residual invasive HER2positive breast cancer. N Engl J Med. 2019; 380(7):617-28.

14 Loibl S, Untch M, Buyse M, Robidoux A, Gianni L, Schneeweiss A, et al. Pathologic complete response ( $\mathrm{pCR}$ ) and prognosis following neoadjuvant chemotherapy plus anti-HER2 therapy of HER2-positive early breast cancer (EBC). San Antonio Breast Cancer Symposium (SABCS); 2019.

15 Cardoso F, Kyriakides S, Ohno S, PenaultLlorca F, Poortmans P, Rubio IT, et al. Early breast cancer: ESMO clinical practice guidelines for diagnosis, treatment and follow-up. Ann Oncol. 2019;30:1674-220. 
16 Denduluri N, Somerfield MR, Chavez-MacGregor M, Comander AH, Dayao Z, Eisen A, et al. Selection of optimal adjuvant chemotherapy and targeted therapy for early breast cancer: ASCO guideline update. J Clin Oncol. 2020 Oct 20:JCO2002510.

17 National Comprehensive Cancer Network (NCCN). Clinical Practice Guidelines in Oncology: Breast Cancer (Version 6.2020). September 8, 2020. Available from: https://www. nccn.org/professionals/physician_gls/pdf/ breast.pdf [accessed 2020 Oct 22].

18 Curigliano G, Sessa C, Buske C, et al. ESMO Pocket Guidelines Breast Cancer. 2020. Available from: http://interactiveguidelines.esmo. org/esmo-web-app/toc/index.php?subject [accessed 2020 Oct 22].

19 Arbeitsgemeinschaft Gynäkologische Onkologie e.V. (AGO) Kommission Mamma. Diagnostik und Therapie früher und fortgeschrittener Mammakarzinome - Adjuvante endokrine Therapie bei prä- und postmenopausalen Patientinnen. 2021. Available from: https: //www.ago-online.de/fileadmin/agoonline/downloads/_leitlinien/kommission_ mamma/2021/Einzeldateien/2021D_10_Adjuvante_Endokrine_Therapie_MASTER_final_20210302.pdf (accessed: 29.04.2021).

20 Perez EA, Romond EH, Suman VJ, Jeong JH, Davidson NE, Geyer CE, et al. Four-year follow-up of trastuzumab plus adjuvant chemotherapy for operable human epidermal growth factor receptor 2-positive breast cancer: joint analysis of data from NCCTG N9831 and NSABP B-31. J Clin Oncol. 2011, 29(25):3366-73.

21 Chumsri S, Li Z, Serie DJ, Mashadi-Hossein A, Colon-Otero G, Song N, et al. Incidence of late relapses in patients with HER2-positive breast cancer receiving adjuvant trastuzumab: combined analysis of NCCTG N9831 (Alliance) and NRG Oncology/NSABP B-31. J Clin Oncol. 2019;37:3425-35.

22 Goldhirsch A, Gelber RD, Piccart-Gebhart MJ, de Azambuja E, Procter M, Suter TM, et al. 2 years versus 1 year of adjuvant trastuzumab for HER2-positive breast cancer (HERA): an open-label, randomised controlled trial. Lancet. 2013;382(9897):1021-8.

23 von Minckwitz G, Procter M, de Azambuja E, Zardavas D, Benyunes M, Viale G, et al. Adjuvant pertuzumab and trastuzumab in early HER2-positive breast cancer. N Engl J Med. 2017;377(2):122-31.

24 Hurvitz SA, Martin M, Symmans WF, Jung KH, Huang CS, Thompson AM, et al. Neoadjuvant trastuzumab, pertuzumab, and chemotherapy versus trastuzumab emtansine plus pertuzumab in patients with HER2-positive breast cancer (KRISTINE): a randomised, open-label, multicentre, phase 3 trial. Lancet Oncol. 2018;19(1):115-26.

25 Cortazar P, Zhang L, Untch M, Mehta K, Costantino JP, Wolmark N, et al. Pathological complete response and longterm clinical benefit in breast cancer: the CTNeoBC pooled analysis. Lancet. 2014;384(9938):164-72.
26 Romond EH, Suman VJ, Jeong JH, et al. Trastuzumab plus adjuvant chemotherapy for HER2-positive breast cancer: final planned joint analysis of overall survival from NSABP B-31 and NCCTG N9831. San Antonio Breast Cancer Symposium (SABCS); 2012. Abstract \#S5-5 and presentation.

27 Vaz-Luis I, Ottesen RA, Hughes ME, Marcom PK, Moy B, Rugo HS, et al. Impact of hormone receptor status on patterns of recurrence and clinical outcomes among patients with human epidermal growth factor-2-positive breast cancer in the National Comprehensive Cancer Network: a prospective cohort study. Breast Cancer Res. 2012;14(5):R129.

28 Strasser-Weippl K, Horick N, Smith IE, O'Shaughnessy J, Ejlertsen B, Boyle F, et al. Long-term hazard of recurrence in HER2+ breast cancer patients untreated with antiHER2 therapy. Breast Cancer Res. 2015;17(1): 56.

29 Lambertini M, Campbell C, Gelber RD, Viale G, McCullough A, Hilbers F, et al. Dissecting the effect of hormone receptor status in patients with HER2-positive early breast cancer: exploratory analysis from the ALTTO (BIG 2-06) randomized clinical trial. Breast Cancer Res Treat. 2019;177(1):103-14.

30 U.S. Food \& Drug Administration (FDA). Approval Neratinib 2017. Available from: https: //www.fda.gov/drugs/resources-information-approved-drugs/fda-approves-neratinib-extended-adjuvant-treatment-earlystage-her2-positive-breast-cancer [accessed 2020 Oct 22].

31 European Medicines Agency (EMA). Approval Neratinib 2018. Available from: https: //www.ema.europa.eu/en/medicines/human/EPAR/nerlynx [accessed 2020 Oct 22].

32 Pierre Fabre Médicament, Summary of Product Characteristics Nerlyn $x^{\oplus} 40$ mg film-coated tablets, July 2020.

33 U.S. Food \& Drug Administration (FDA). Approval Neratinib 2020. Available from: https: //www.fda.gov/drugs/resources-information-approved-drugs/fda-approves-neratinib-metastatic-her2-positive-breast-cancer [accessed 2020 Oct 22].

34 SwissMedic. Zulassung Neratinib 2020. Available from: https://www.swissmedicinfo. ch/ [accessed 2020 Oct 22].

35 European Medicines Agency (EMA). Neratinib - Public Assessment Report [EMA/ CHMP/525204/2018], 13. Juli 2018. Available from: https://www.ema.europa.eu/en/documents/assessment-report/nerlynx-epar-public-assessment-report_en.pdf [accessed 2020 Oct 22].

36 Chan A, Delaloge S, Holmes FA, Moy B, Iwata H, Harvey VJ, et al. Neratinib after trastuzumab-based adjuvant therapy in patients with HER2-positive breast cancer (ExteNET): a multicentre, randomised, double-blind, placebo-controlled, phase 3 trial. Lancet Oncol. 2016;17(3):367-77.

37 Martin M, Holmes FA, Ejlertsen B, Delaloge $\mathrm{S}$, Moy B, Iwata H, et al. Neratinib after trastuzumab-based adjuvant therapy in HER2-positive breast cancer (ExteNET): 5-year analysis of a randomised, double-blind, placebo-controlled, phase 3 trial. Lancet Oncol. 2017; 18(12):1688-700.
38 Chan A, Moy B, Mansi J, Ejlersten B, Holmes FA, Chia S, et al. Final efficacy results of neratinib in HER2-positive hormone receptorpositive early-stage breast cancer from the phase III ExteNET trial. Clin Breast Cancer. 2021;21:80-91.

39 Martin M, Gnant M, Ejlertsen B et al. Impact of treatment duration of extended adjuvant therapy with neratinib on patient outcomes in early-stage HER2+ HR+ breast cancer after trastuzumab-based therapy. Poster No.83P presented at the ESMO Breast Virtual Meeting 23-24 May 2020.

40 Delaloge S, Cella D, Ye Y, Buyse M, Chan A, Barrios $\mathrm{CH}$, et al. Effects of neratinib on health-related quality of life in women with HER2-positive early-stage breast cancer: longitudinal analyses from the randomized phase III ExteNET trial. Ann Oncol. 2019; 30(4):567-74.

41 Boehringer Ingelheim International $\mathrm{GmbH}$. Summary of Product Characteristics Giotrif November 2019.

42 Novartis Pharma GmbH. Summary of Product Characteristics Tyverb ${ }^{\oplus}$. September 2019.

43 Hartmann JT, Haap M, Kopp HG, Lipp HP. Tyrosine kinase inhibitors - a review on pharmacology, metabolism and side effects. Curr Drug Metab. 2009;10(5):470-81.

44 Mortimer J, Di Palma J, Schmid K, Ye Y, Jahanzeb M. Patterns of occurrence and implications of neratinib-associated diarrhea in patients with HER2-positive breast cancer: analyses from the randomized phase III ExteNET trial. Breast Cancer Res. 2019;21(1):32.

45 Fontanella C, Bolzonello S, Lederer B, Aprile $\mathrm{G}$. Management of breast cancer patients with chemotherapy-induced neutropenia or febrile neutropenia. Breast Care (Basel). 2014; 9(4):239-45.

46 Hansen RN, Ramsey SD, Lalla D, Masaquel A, Kamath T, Brammer M, et al. Identification and cost of adverse events in metastatic breast cancer in taxane and capecitabine based regimens. Springerplus. 2014;3:259.

47 Issa DE, Gelderblom H, Lugtenburg PJ, van Herk-Sukel MP, Houweling LMA, De La Orden $\mathrm{M}$, et al. Healthcare utilisation in patients with breast cancer or non-Hodgkin lymphoma who experienced febrile neutropenia in the Netherlands: a retrospective matched control study using the PHARMO database. Eur J Cancer Care (Engl).. 2015;24(2):232-41.

48 Xu ZQ, Zhang Y, Li N, Liu PJ, Gao L, Gao X, et al. Efficacy and safety of lapatinib and trastuzumab for HER2-positive breast cancer: a systematic review and meta-analysis of randomised controlled trials. BMJ Open. 2017; 7(3):e013053.

49 Pierre Fabre Pharma Austria. Nerlynx ${ }^{\oplus}$ Schulungsmaterial für Ärzte zum DiarrhoeManagement. Version 1/2019, November 2019. Available from: https://www.oncosite. de/files/content/docs/fachkreise/nerlynx/ Nerlynx_RMP_Broschuere_Aerzte_AT.pdf [accessed 2020 Oct 22]. 
50 Pierre Fabre Pharma Austria. Nerlynx ${ }^{\circledast}-$ Behandlungsleitfaden für Patienten/Betreuer Massnahmen bei Durchfall während der Behandlung mit Neratinib. Version 1/2019, November 2019. Available from: https://www. oncosite.de/files/content/docs/fachkreise/ nerlynx/Nerlynx_RMP_Therapieleitfaden_ Patienten_AT.pdf [accessed 2020 Oct 22].

51 Pierre Fabre Pharma Austria. Nerlynx ${ }^{\oplus}-\mathrm{Be}$ handlungstagebuch. Version 1/2019, November 2019. Available from: https://www. oncosite.de/files/content/docs/fachkreise/ nerlynx/Nerlynx_RMP_Patiententagebuch_ AT.pdf [accessed 2020 Oct 22].

52 ClinicalTrials.gov. NCT02400476 - An open-label study to characterize the incidence and severity of diarrhea in patients with early-stage HER2+ breast cancer treated with neratinib and loperamide. 2020. Available from: https://clinicaltrials.gov/ct2/ show/NCT02400476? cond=NCT02400476\& draw $=2 \&$ rank $=1$ [accessed 2020 Oct 22].

53 Barcenas CH, Hurvitz SA, Di Palma JA, Bose $\mathrm{R}$, Chien AJ, Iannotti N, et al. Improved tolerability of neratinib in patients with HER2positive early-stage breast cancer: the $\mathrm{CON}$ TROL trial. Ann Oncol. 2020;31(9):1223-30.
54 Ruiz-Borrego M, Chan A, Marx G, Brufsky A, Chien AJ, Trudeau M, et al. Bringing diarrhea under CONTROL: dose escalation reduces neratinib-associated diarrhea and improves tolerability in HER2-positive early-stage breast cancer.

55 Arbeitsgemeinschaft Gynäkologische Onkologie e.V. (AGO) Kommission Mamma. Diagnostik und Therapie früher und fortgeschrittener Mammakarzinome - Supportive Therapie und Nebenwirkungsmanagement. 2021. Available from: https://www.ago-online.de/fileadmin/ago-online/downloads/ leitlinien/kommission_mamma/2021/ Einzeldateien/2021D_14_Supportive_Therapie_und_NW-Management_MASTER_final_20210302.pdf [accessed: 2021 Apr 29].

56 Gemeinsamer Bundesausschuss (G-BA). Beschlusstext des Gemeinsamen Bundesausschusses über eine Änderung der Arzneimittel-Richtlinie (AM-RL): Anlage XII - Nutzenbewertung von Arzneimitteln mit neuen Wirkstoffen nach $\$ 35$ a SGB V Neratinib (Mammakarzinom, HR-positiv, HER2-positiv, adjuvante Behandlung. 14.05.2020. Available from: https://www.g-ba.de/downloads/39-261-4290/2020-05-14_AM-RL_ XII_Neratinib_D-506_BAnz.pdf [accessed 2020 Oct 22].
57 National Institute for Health and Care Excellence (NICE). Neratinib for extended adjuvant treatment of hormone receptor-positive, HER2-positive early stage breast cancer after adjuvant trastuzumab, NICE Guidance. 20. November 2019. Available from: https:// www.nice.org.uk/guidance/ta612/resources/ neratinib-for-extended-adjuvant-treatmentof-hormone-receptorpositive-her2positiveearly-stage-breast-cancer-after-adjuvanttrastuzumab-pdf-82608953431237 [accessed: 2020 Dec 16].

58 Scottish Medicines Consortium (SMC). Advice: Neratinib (NERLYNX), SMC No. SMC2251 Aug 10, 2020. Available from: https://www.scottishmedicines.org.uk/medicines-advice/neratinib-nerlynx-fullsmc2251/ [accessed: 2020 Dec 16).

59 Tandvårds- och läkemedelsförmånsverket, (TLV) Available from: https://www.tlv.se/ beslut/beslut-lakemedel/generell-subvention/arkiv/2020-02-25-nerlynx-neratinib-ingar-i-hogkostnadsskyddet.html [accessed: 2020 Dec 17]

60 Österreichische Sozialversicherung: Der Erstattungskodex. Available from: https://www. sozialversicherung.at/cdscontent/?content $\mathrm{id}=10007.844497 \&$ portal=svportal [last updated: 2020 Nov 14, accessed: 2021 May 3] 